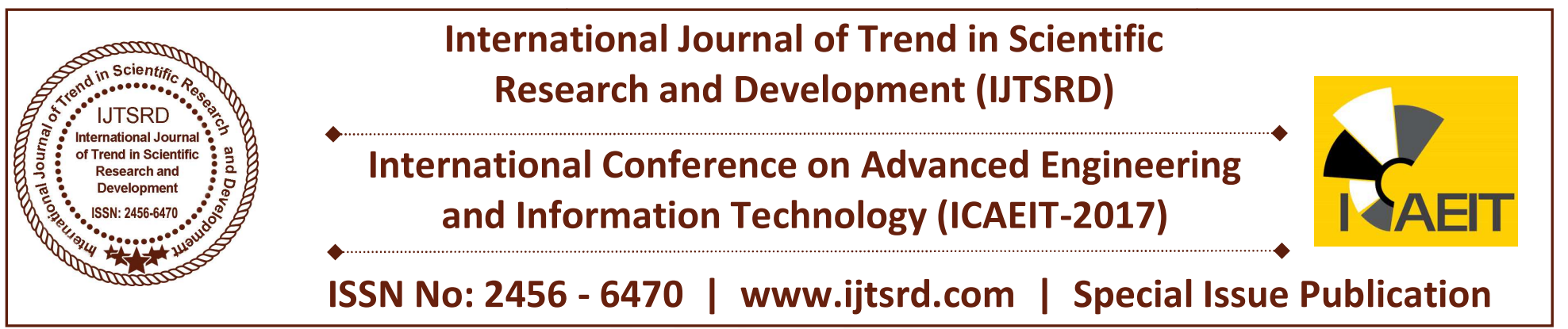

\title{
Effect of Tsunami Loads on Ulak Karang Shelter Building in Padang City
}

\author{
Fauzan, Febrin Anas Ismail, Annisa El Husna, Zev Al Jauhari, Silvia \\ Department of Civil Engineering, Engineering Faculty, Andalas University, Indonesia
}

\begin{abstract}
In recent years, tsunami surges several regions in Indonesia, particularly in Sumatera Island which cause the damage to various facilities and infrastructures, even inflicting considerable casualties. The last strong undersea earthquake in Mentawai, West Sumatera on 2009, has warned the government to face the tsunami disaster in next big earthquake. Therefore, it is needed rescue strategies (mitigation) in the form of vertical evacuation in high and strong buildings, one of which is in the form of providing shelter at vulnerable area to tsunami. Padang City has built a five-story shelter building made of Reinforced Concrete Structures located in Ulak Karang, North Padang. Based on the review, there is no tsunami loads consider by the design consultant in designing the shelter due to there is no Indonesian standard code in designing the shelter building. Actually, the tsunami loads should be considered if the shelter will be used for evacuation due to earthquake and tsunami. This paper presents the effect of tsunami loads on Ulak Karang Shelter structure. The comparison of structural responses on the shelter structure with and without impacted by tsunami loads based on FEMA646 standard code was also discussed.
\end{abstract}

Keywords: Tsunami loads, earthquake, internal forces, load-bearing capacity, shelter, FEMA P-646

\section{INTRODUCTION}

West Sumatra province, especially in Padang City, is an area that prone to earthquake and tsunami because it was loacated in the two plate adjacent (Indian and Asian coastline). Earthquake in West Sumatra is a kind of strong earthquakes that could lead to a tsunami. In addition to vulnerable areas, population density distribution of Padang is very alarming. Therefore, when the tsunami happens, population of the city would be difficult to be evacuated horizontally, experiencing traffic congestion due to the unsufficient road infrastructure in Padang City. Therefore, it is necessary to evacuate vertically in tall and strong buildings to minimize the risk of casualties during the tsunami.

One of them is establishing the provision of Temporary Evacuation Sites (TES) around areas that prone of tsunami, which can protect the people living in the area of the tsunami disaster. Because the affected areas are generally located close to the source of the earthquake, the TES building must also meet the requirements of earthquake-resistant buildings.

Therefore, the government of Padang City takes action to plan a TES namely Ulak Karang Shelter, in North Padang (Fig. 1), to be used as a vertical evacuation when a big earthquake occurs followed by tsunami. Thus, in designing a shelter building, it must be pay attention and detail to input the working loads in the building such as dead, live, earthquake, and tsunami loads.

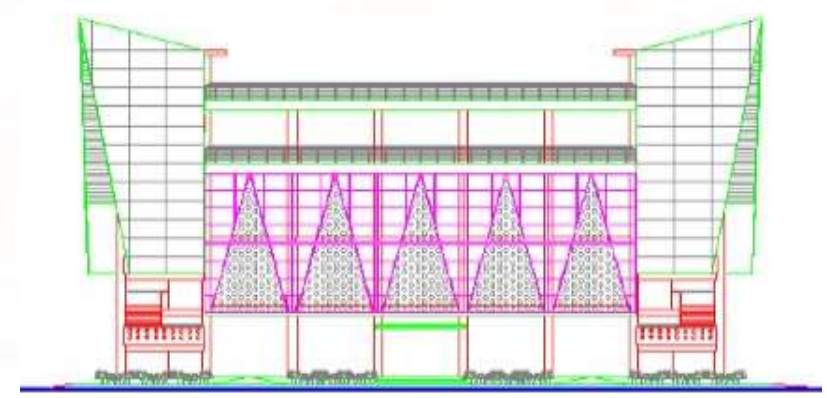

(a) Front view 


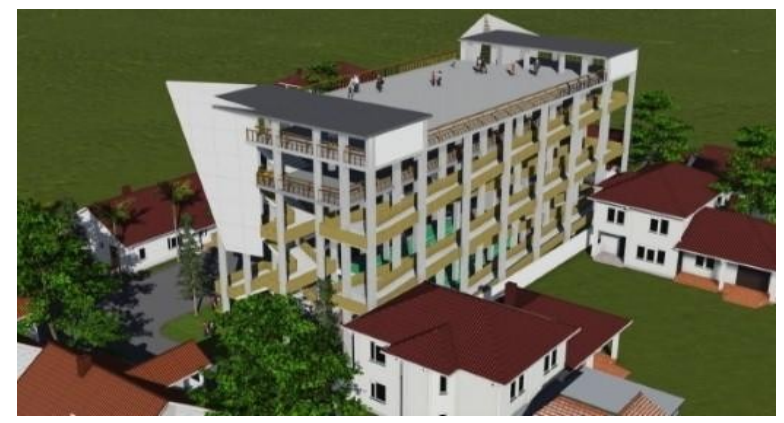

(b) $3 \mathrm{D}$ view

Figure1. Front and 3D view of Ulak Karang Shelter Building [2]

However, the design consultant did not consider the tsunami loads in designing the structure of the Ulak Karang Shelter due to there is no standard code in Indonesia for designing the tsunami shelter. Therefore, the structures of Ulak karang shelter should be evaluated before using as a vertical evacuation building due to tsunami disaster. In this study, the Ulak Karang Shelter was evaluated based on FEMA-646 standard code [1].

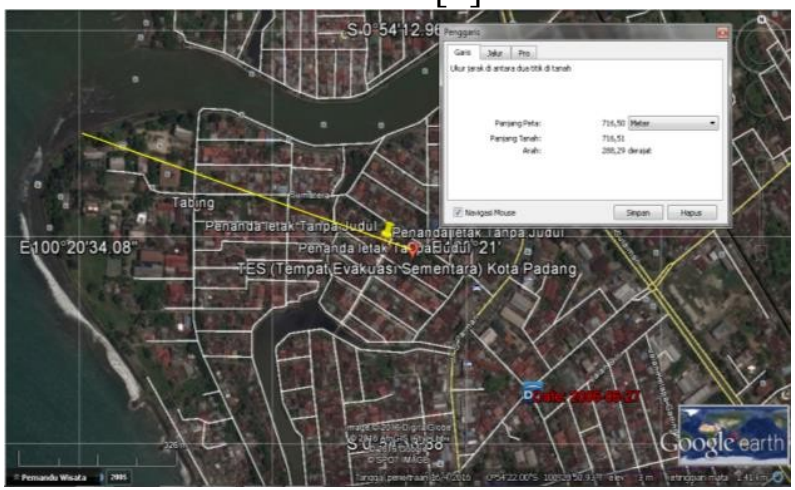

Figure2. Location of shelter [Google Earth]

\section{Structural analysis}

Feasibility evaluation of the structure consists of serviceability limit performance evaluation, performance ultimate limit that determined by the story drift, the axial and bending moment capacity of the column using the column $\mathrm{P}-\mathrm{M}$ interaction diagram, and the load-bearing capacity of beam [3]. The Ulak Karang Shelter located in Padang City, with position at $\pm 700 \mathrm{~m}$ from the beach of Padang (Fig. 2). The building is five- story reinforced concrete frame structure. The structure consists of columns, beams and slabs. The shape of the building is rectangular with area of $672 \mathrm{~m} 2$. Ulak Karang Shelter Building has height of 20,65 m excluding the roof, number of columns each floor is 56 , with two different sizes, dimensions: D-60 cm and $60 \mathrm{~cm} \times 40 \mathrm{~cm}$. Each column is associated with three types of beam size with dimensions: $40 \mathrm{~cm}$ x $60 \mathrm{~cm}, 40 \mathrm{~cm}$ x $50 \mathrm{~cm}$, and $30 \mathrm{~cm} \times 30 \mathrm{~cm}$. Concrete strength was K-350 ( $\mathrm{fc}^{\prime}=$
$29,05 \mathrm{MPa}$ ) and yield strength of reinforcement (fy) was $400 \mathrm{MPa}$. All working loads are taken into account including the dead load / weight of its own building, live load, seismic (earthquake) load, and tsunami loads.

\subsection{Design of loads}

The standard code of the minimum load for design of buildings and other structures, SNI 1727-2013 [4], was used to design the loads of the building. The working loads include live load, dead load and seismic load. The dead load includes all components of the building structure, namely beams, columns, plates, and load-bearing walls. Live load used was $250 \mathrm{~kg} / \mathrm{m} 2$, where the function of the building is as office and evacuation building.

\subsection{Earthquake Response Spectrum}

Seismic load based on SNI 1726-2012 using response spectrum was obtained from the website http://puskim.pu.go.id/Aplikasi/desain_spektra_indon esi a_2011/ by entering the name of city. Figure 3 shows the response spectrum of Padang City with soft soil type. The value of spectral design SD1 and SDS are $0,6 \mathrm{~g}$ and $0,932 \mathrm{~g}$, respectively [5].

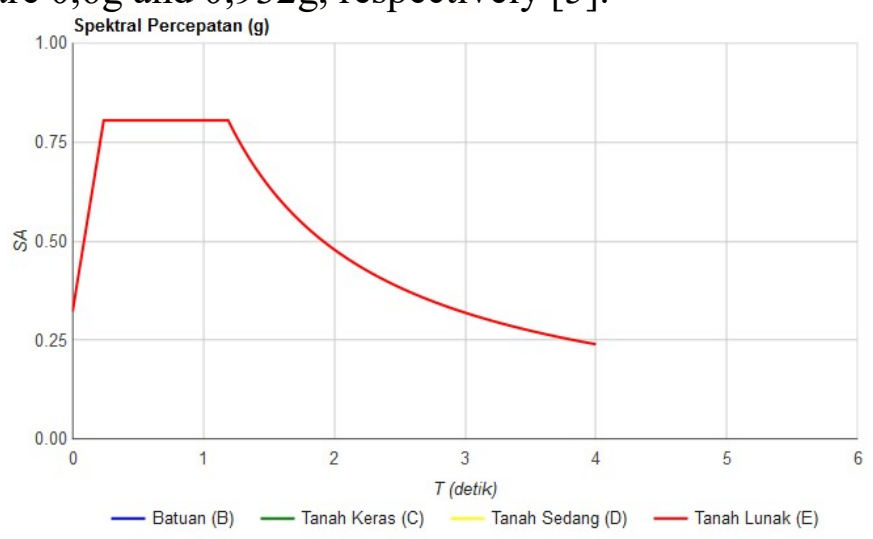

Figure3. Earthquake response Spectrum design of Padang City [5]

\subsection{Tsunami loads}

Tsunami loads are calculated based on the FEMA P646 Code, which is published on April 2012.

\subsubsection{Hydrostatic Force}

Hydrostatic force is the horizontal force that caused by the water pressure against to a surface. The amount of this force depends on the depth of water [1]. Hydrostatic force can be calculated by the equation:

$$
\begin{aligned}
& F_{\&} \quad p A^{A} 0.5 . g b h{ }^{2} \text { nax } \\
& h_{\max } 13 R \quad z_{3}
\end{aligned}
$$


Where:

Fh is hydrostatic force,

pc is hydrostatic pressure at the central of the wetted, portion of the wall panel,

Aw is the wetted area of the panel, ps is weight/ volume of tsunami $(1100 \mathrm{~kg} / \mathrm{m} 3)$,

$\mathrm{g}$ is acceleration of gravity,

$\mathrm{b}$ is width that accept the pressure,

hmax is the maximum of water height above the wall base,

$\mathrm{R}^{*}$ is the maximum run up elevation of tsunami, $\mathrm{zW}$ is the height of wall panel,

These loads are given by equal triangles on tsunami submerged area, as seen in the Fig. 4.

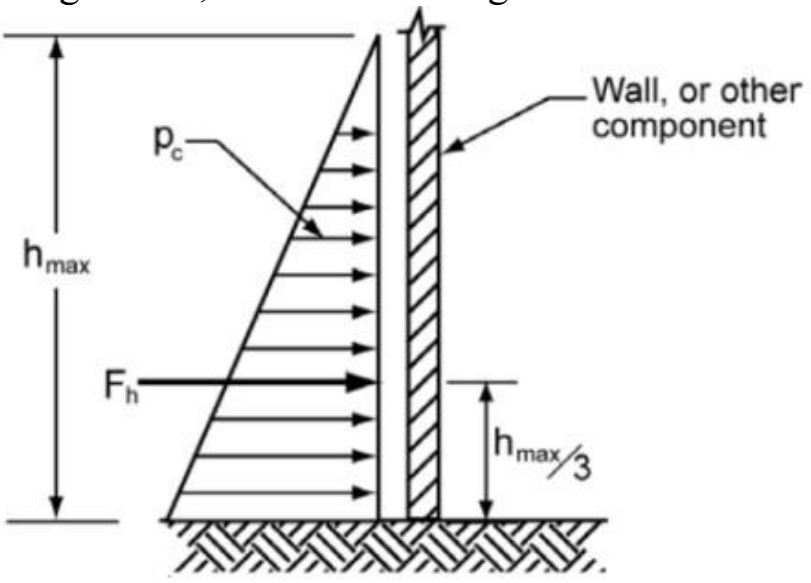

Figure4. Distribution of hydrostatic load [1]

\subsubsection{Bouyant Force}

The buoyant forces on a structure subject to partial or total submergence will act vertically through the center of mass of the displaced volume. Buoyant forces are a concern for wood frame buildings, empty above-ground and below-ground tanks. For evaluation of an individual floor panel where the water level outside differs substantially from the level inside [1]. The buoyant force on the structure can be calculated by the equation:

$$
F_{b}, g . V
$$

where:

$\mathrm{Fb}$ is the bouyant force,

$\mathrm{V}$ is the volume of water below the maximum inundation.

The buoyant force was distributed load on the top floor that flooded by the tsunami, as seen in the Figure 5.

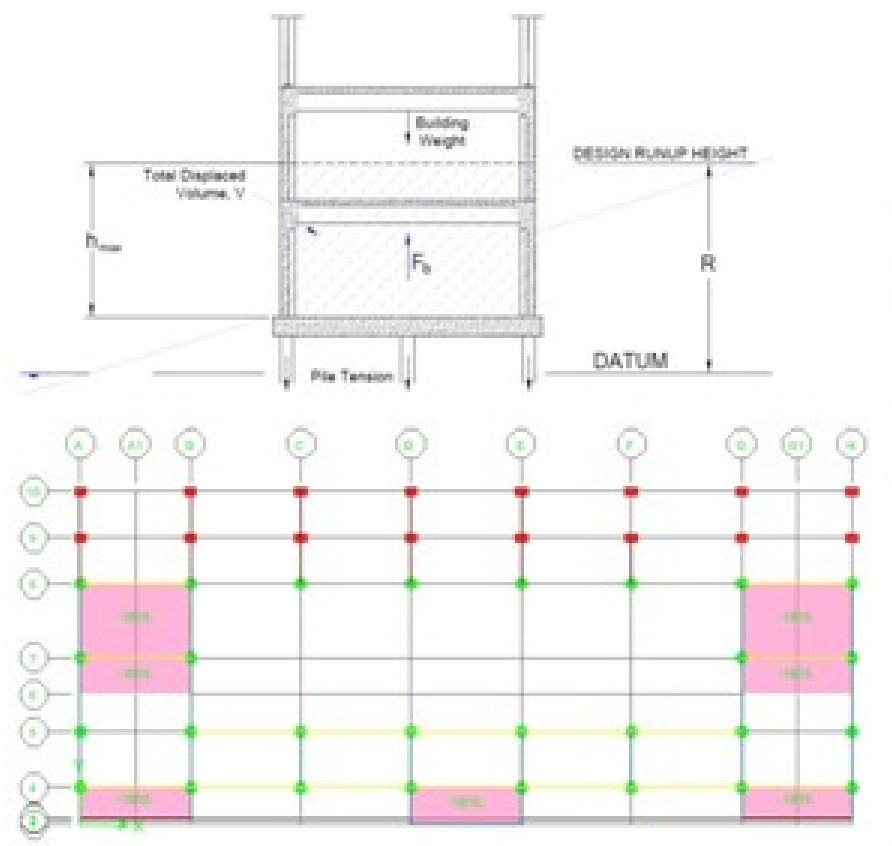

Figure5. The acting of buoyant force on the structure of Ulak Karang Shelter

\subsubsection{Hydrodinamic Force}

Hydrodynamic force is a combination of horizontal forces caused by the compressive force of moving water and the friction caused by the flow around the structure [1].

Hydrodynamic force can be calculated by the equation

$$
F_{4} \quad 0,5, C_{d} \cdot B\left(h u^{2}\right)
$$

where:

$\mathrm{Fd}$ is hydrodynamic force

$\mathrm{Cd}$ is the drag coefficient $=2$

$\mathrm{B}$ is the width of structure

$h$ is the depth of flow

$\mathrm{u}$ is the flow velocity

Hydrodynamic force is distributed load on the heigth of column affected tsunami flow, as seen in the Figure 6.

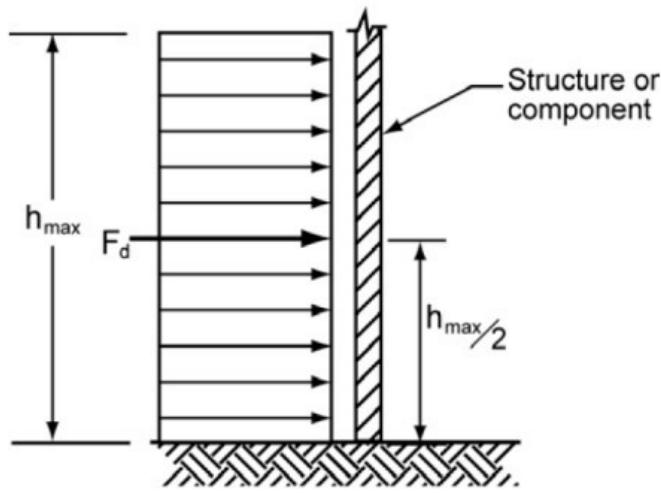




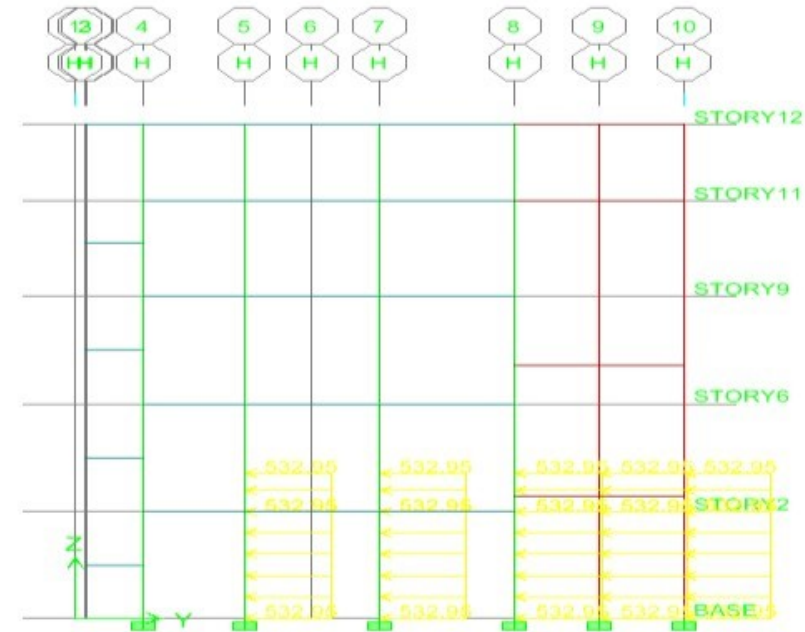

Figure6. Distribution of hydrodynamic load on the structure of Ulak Karang Shelter

\subsubsection{Surge Force (Impulse Force)}

Surge forces are caused by the leading edge of a surge of water impinging on a structure and by the water wave that comes suddenly. Surge force of the building is 1.5 times the hydrodynamic force (Fig. 7).

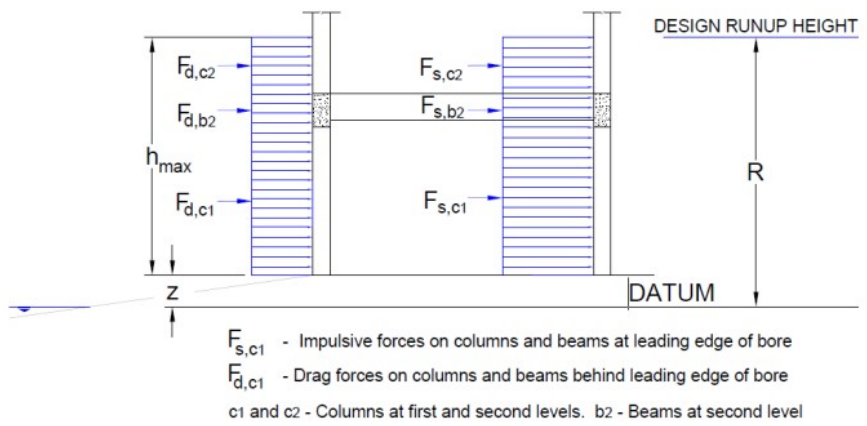

Figure7. Surge force on the structure of Ulak Karang Shelter

\subsubsection{Impact load}

Impact loads are those that result from debris such as driftwood, small boats, portions of house, or any object transported by floodwaters, striking against buildings and structures. The influence of the mass of debris that swept by water can be a major cause of building damage. The force is difficult to establish accurate values. As an approach, this value is calculated by the following equation:

$$
F_{i} \quad 1,3 \cdot u_{\max } \sqrt{k \cdot m_{d}(1 \mathrm{c})}
$$

where:

Fi is impact force

umax is the maximum flow

$\mathrm{k}$ is the stiffness of debris mass

$\mathrm{md}$ is the mass of debris

$\mathrm{c}$ is hydrodinamic coefficient
The impact force is distributed load to the structural elements that affected the first part of the tsunami flow, as seen in the Figure 8.

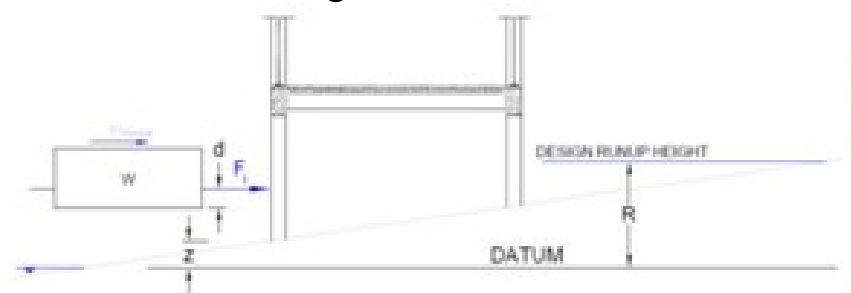

Figure8. Impact load on the structure of Ulak Karang Shelter

\subsubsection{Debris load}

Debris impact is caused by a buildup of debris that assumed by additional hydrodynamic force and depends on the thickness of the layer of debris. To calculate the debris force, use the equation:

$$
F_{d i m} 0,5 ., \quad C_{d} \cdot B_{d}\left(h u^{2}\right)^{2}
$$

where:

Fdm is debris force

$\mathrm{Bd}$ is breadth

\subsubsection{Extra gravity load}

Water suspended above the floor will be an additional load of gravity before the entire pool of back retroactively. The depth of stagnant water depending on the maximum height and horizontal forces flooded walls. Due to the high depreciation rate of water is rapid, it is likely that there will plenty of water suspended in the floor, causing the addition of a significant gravitational force on the floor (Fig. 9). Potential extra load of gravity per unit area can be calculated by the equation:

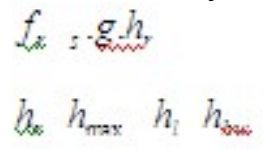

where:

fr is extra gravity load 
$\mathrm{hr}$ is the maximum depth of water suspended in the floor

hmax is expected maximum height of inundation $\mathrm{hl}$ is the maximum height of inundation predicted hbw is the maximum depth of water suspended prior to wall failure due to hydrostatic force

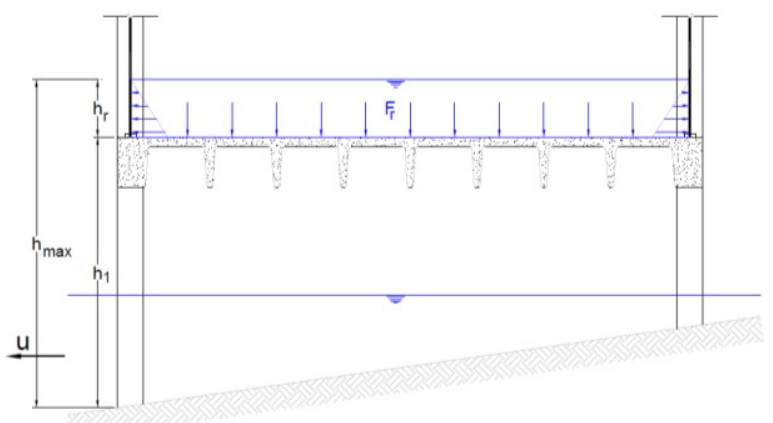

Figure9. Extra gravity load on the structure of Ulak Karang Shelter

\subsubsection{Uplift hydrodinamic load}

Uplift hydrodynamic force is given on the top floor of the tsunami inundation affected, as shown in Fig. 10. This load can be calculated by the equation:

$F_{d m} 0,5 . C_{d} \cdot B_{d}\left(h u^{2}\right)_{\max }$

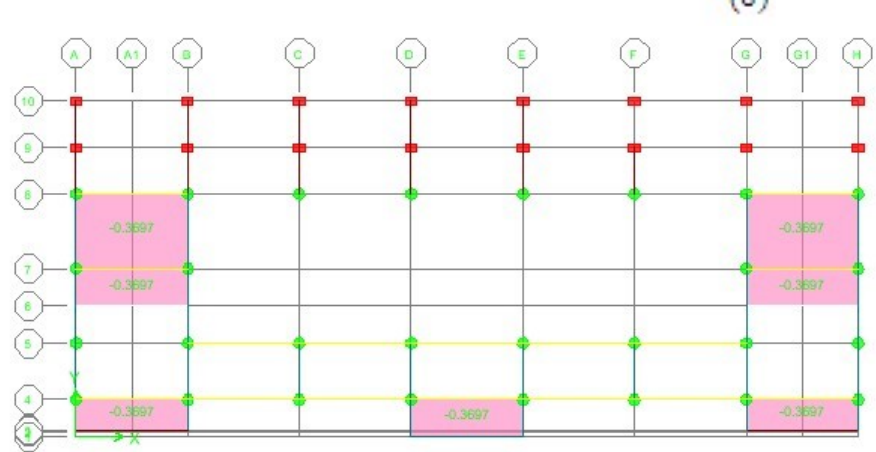

Figure10. Uplift hydrodinamic load on the structure of Ulak Karang Shelter

The value of each loads were calculated based on the predictions of tsunami height, shelter sub gradeelevation, distance from the waterfront, and other assumptions, as seen in the Fig. 11. The calculation results of tsunami loads is given in Table 1. Elevation shelter that safe from tsunami inundation is calculated based on the standard FEMA 646, as follows:

1. Data Map Tsunami Plan and Google Earth 8.

2. Elevation basic structure (Google Earth) $(Z)=3$ mdpl

3. Run-up (Tsunami Hazard Maps) $\left(\mathrm{R}^{*}\right)=7 \mathrm{mdpl}$

4. Run-up Design $(\mathrm{R})=9.1 \mathrm{mdpl}$

5. Maximum Depth of Puddle $($ hmax $)=6.1 \mathrm{~m}$

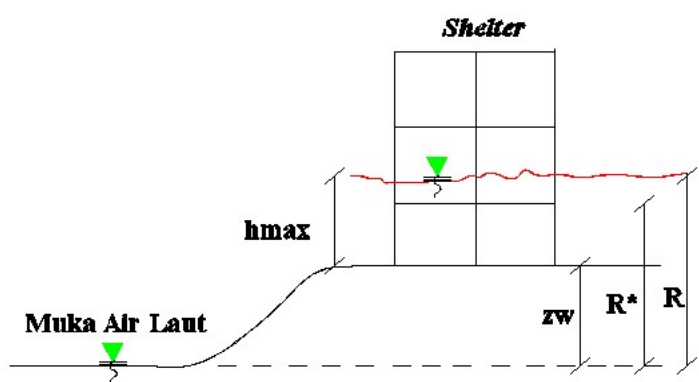

Figure11. Plan puddle of tsunami

Table 1: Type and value of tsunami loads on the structure of Ulak Karang Shelter

\begin{tabular}{|l|l|l|}
\hline Code & Type of Tsunami Load & Value of Force \\
\hline $\mathrm{Fh}$ & *Hydrostatic & $1279.3 \mathrm{~kg}$ \\
\hline $\mathrm{Fb}$ & Bouyant & $1815 \mathrm{~kg}$ \\
\hline $\mathrm{Fd}$ & Hydrodinamic & $3251 \mathrm{~kg}$ \\
\hline $\mathrm{Fs}$ & Surge/ Impulse & $4876.49 \mathrm{~kg}$ \\
\hline $\mathrm{Fi}$ & Impact & $47643.17 \mathrm{~kg}$ \\
\hline $\mathrm{Fdm}$ & Debris & $3251 \mathrm{~kg}$ \\
\hline $\mathrm{Fu}$ & Uplift of Hydrodinamic & $0.37 \mathrm{~kg} / \mathrm{m} 2$ \\
\hline $\mathrm{Fr}$ & Extra Gravity & $1978.35 \mathrm{~kg} / \mathrm{m} 2$ \\
\hline
\end{tabular}

2.3. The Importance of building factor (Ie), reduction seismic factor $(R)$, and redudancy factor ( $\rho)$

Based on SNI 1726-2012, the shelter building has earthquake risk category of IV with the Importance of the Building Factor $(\mathrm{Ie})=1.5$. Reduction Seismic Factor (R) is 6.0 for the evacuation and office building (reinforced concrete building). For the planned structure with seismic design category $\mathrm{D}$, the redundancy value $(\rho)$ is 1.3 .

\subsection{Combination of loads}

Combination of loads in SNI 1726-2012 (Earthquake code) was used, which was combined with the combination of tsunami loads based on FEMA P-646:

1. $1,2 \mathrm{D}+1 \mathrm{Fd}+1 \mathrm{Fs}+1 \mathrm{Fb}+1 \mathrm{Fu}+1 \mathrm{LREF}+0,25 \mathrm{~L}$

2. $1,2 \mathrm{D}+1 \mathrm{Fi}+1 \mathrm{Fd}+1 \mathrm{Fb}+1 \mathrm{Fu}+1 \mathrm{LREF}+0,25 \mathrm{~L}$

3. $1,2 \mathrm{D}+1 \mathrm{Fd}+1 \mathrm{Fdm}+1 \mathrm{Fb}+1 \mathrm{Fu}+1 \mathrm{LREF}+0,25$ $\mathrm{L}$

4. $1,2 \mathrm{D}+1 \mathrm{Fr}+1 \mathrm{Fb}+1 \mathrm{Fu}+1 \mathrm{LREF}+0,25 \mathrm{~L}$

5. $0,9 \mathrm{D}+1 \mathrm{Fd}+1 \mathrm{Fs}+1 \mathrm{Fb}+1 \mathrm{Fu}$

6. $0,9 \mathrm{D}+1 \mathrm{Fi}+1 \mathrm{Fd}+1 \mathrm{Fb}+1 \mathrm{Fu}$

7. $0,9 \mathrm{D}+1 \mathrm{Fd}+1 \mathrm{Fdm}+1 \mathrm{Fb}+1 \mathrm{Fu}$

8. $0,9 \mathrm{D}+1 \mathrm{Fr}+1 \mathrm{Fb}+1 \mathrm{Fu}$

where:

$\mathrm{D}=$ Dead Load

$\mathrm{L}=$ Life Load

LREF $=$ Life Refugee Load

$\mathrm{Fi}=$ Impact Load 
Fdm $=$ Debris Dam Load

$\mathrm{Fd}=$ Hydrodynamic Load

Fs $=$ Impulsive Load

$\mathrm{Fb}=$ Buoyant Load

$\mathrm{Fu}=$ Uplift Load

\subsection{Modeling of Structure}

The building is modeled into 3D and then analyzed by using structural analysis program, ETABS v9.7.1 [7]. Columns and beams are modeled as an element of the frame, while the slabs are modeled as shell element. Modeling of the building structure is performed in accordance with the drawing of the design consultant. Figure 12 shows the structural modeling of Ulak Karang Shelter Building.

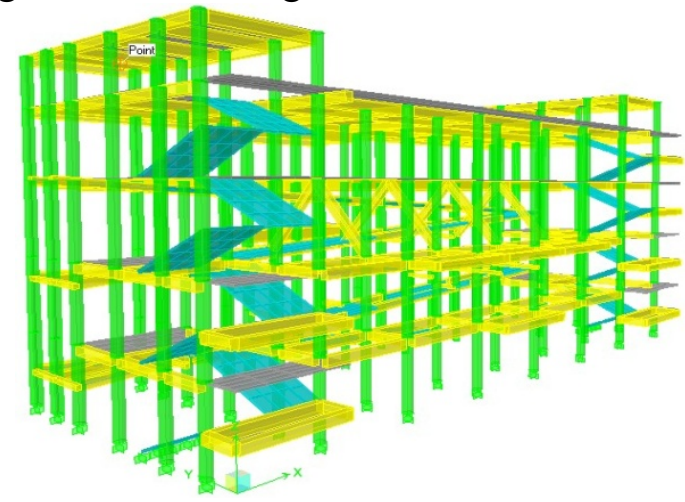

Figure12. 3-D Modelling of Ulak Karang Shelter Structure

\section{Result and discussion}

\subsection{Inter story drift}

Based on SNI 1726-2012, the inter story drift $(\Delta)$ must be calculated as using the following equation:

$$
\text { s. } \frac{a d}{I e}
$$

where:

$\Delta=$ Inter story drift

$\Delta \mathrm{a}=$ Inter story drift allowable

$\mathrm{Cd}=$ Enlargement deflection factor

$\mathrm{Ie}=$ Importance of the building factor $\mathrm{h}=$ Height of each floor

$\delta=$ Difference of story drift

$\rho=$ Redundancies factor

Tables 2 and 3 show the inter story drift value of building structure analyzed by using SNI 03-17262012 and FEMA in $\mathrm{x}$ and $\mathrm{y}$-directions, respectively. From the tables, it can be seen that the maximum of story drift for $\mathrm{x}$ and $\mathrm{y}$-direction of structure with tsunami loads are $0.0281 \mathrm{~m}$ and $0.0490 \mathrm{~m}$, respectively. These values are less than the allowable inter story drift of $0.0519 \mathrm{~m}$, so it means that the Ulak Karang Shelter building structure is capable of resisting the working loads.

Table 2: Interstory drift of structure without tsunami loads

\begin{tabular}{|c|c|c|c|c|c|}
\hline Story & $\begin{array}{c}\text { Disp. } \\
(\mathrm{mm})\end{array}$ & $\begin{array}{c}\text { Drift } \mathbf{X} \\
(\mathrm{mm})\end{array}$ & $\begin{array}{c}\Delta \mathrm{s} \\
(\mathrm{mm})\end{array}$ & $\begin{array}{c}\Delta \mathrm{a} \\
(\mathrm{mm})\end{array}$ & $\begin{array}{c}\Delta \mathrm{s} \leq \\
\mathbf{\Delta a}\end{array}$ \\
\hline 1 & 5.43 & 5.43 & 19.910 & 51.346 & OK \\
\hline 2 & 13.18 & 7.75 & 28.417 & 51.923 & OK \\
\hline 3 & 18.95 & 5.77 & 21.157 & 51.923 & OK \\
\hline 4 & 22.62 & 3.67 & 13.457 & 46.154 & OK \\
\hline 5 & 24.52 & 1.9 & 6.967 & 36.923 & OK \\
\hline
\end{tabular}

\begin{tabular}{|c|c|c|c|c|c|}
\hline Story & $\begin{array}{c}\text { Disp. } \\
(\mathbf{m m})\end{array}$ & $\begin{array}{c}\text { DriftY } \\
(\mathbf{m m})\end{array}$ & $\begin{array}{c}\Delta \mathbf{s} \\
(\mathbf{m m})\end{array}$ & $\begin{array}{c}\Delta \mathbf{a} \\
(\mathbf{m m})\end{array}$ & $\begin{array}{c}\Delta \mathbf{s} \leq \\
\mathbf{\Delta a}\end{array}$ \\
\hline 1 & 10.93 & 10.93 & 40.08 & 51.346 & OK \\
\hline 2 & 24.1 & 13.17 & 48.29 & 51.923 & OK \\
\hline 3 & 26.15 & 2.05 & 7.517 & 51.923 & OK \\
\hline 4 & 29.85 & 3.7 & 13.567 & 46.154 & OK \\
\hline 5 & 32.29 & 2.44 & 8.947 & 36.923 & OK \\
\hline
\end{tabular}

Table 3: Interstory drift of structure with tsunami loads

\begin{tabular}{|c|c|c|c|c|c|}
\hline Story & $\begin{array}{c}\text { Disp. } \\
(\mathrm{mm})\end{array}$ & $\begin{array}{c}\text { Drift X } \\
(\mathrm{mm})\end{array}$ & $\begin{array}{c}\Delta \mathrm{s} \\
(\mathrm{mm})\end{array}$ & $\begin{array}{c}\Delta \mathrm{a} \\
(\mathrm{mm})\end{array}$ & $\begin{array}{c}\Delta \mathrm{s} \leq \\
\mathbf{a}\end{array}$ \\
\hline 1 & 5.5 & 5.5 & 20.167 & 51.346 & OK \\
\hline 2 & 13.18 & 7.68 & 28.160 & 51.923 & OK \\
\hline 3 & 18.95 & 5.77 & 21.157 & 51.923 & OK \\
\hline 4 & 22.55 & 3.6 & 13.200 & 46.154 & OK \\
\hline 5 & 24.59 & 2.04 & 7.480 & 36.923 & OK \\
\hline
\end{tabular}

\begin{tabular}{|c|c|c|c|c|c|}
\hline Story & $\begin{array}{c}\text { Disp. } \\
(\mathbf{m m})\end{array}$ & $\begin{array}{c}\text { Drift } \mathbf{Y} \\
(\mathbf{m m})\end{array}$ & $\begin{array}{c}\Delta \mathrm{s} \\
(\mathbf{m m})\end{array}$ & $\begin{array}{c}\Delta \mathrm{a} \\
(\mathbf{m m})\end{array}$ & $\begin{array}{c}\Delta \mathrm{s} \leq \\
\mathbf{a}\end{array}$ \\
\hline 1 & 10.83 & 10.83 & 39.710 & 51.346 & OK \\
\hline 2 & 24.2 & 13.37 & 49.023 & 51.923 & OK \\
\hline 3 & 26.05 & 1.85 & 6.783 & 51.923 & OK \\
\hline 4 & 29.85 & 3.8 & 13.933 & 46.154 & OK \\
\hline 5 & 32.29 & 2.44 & 8.947 & 36.923 & OK \\
\hline
\end{tabular}

\subsection{Internal Force of Columns and Beams}

Table 4 show the results of internal forces on columns with and without tsunami loads. It can be seen from the table that the internal forces on interior column with tsunami loads calculated based on FEMA P-646 was higher than those calculated without tsunami loads. The values of axial, shear and bending moment 
International Journal of Trend in Scientific Research and Development (IJTSRD) | ISSN: 2456-647

of the columns increase byaround $5-27 \%, 9-49 \%$, and the shear and bending moment of the beam with $18-49 \%$, respectively.

tsunami loads using FEMA P-646 was increase by around $7-39 \%$ and $8-45 \%$, respectively. The higher of

The internal forces on the beams show similar the internal forces especially occurs in the columns of tendency with the column results. As seen in Tables 5,

the 1 st floor and in the beams on the 2 nd floor.

Table 4: Internal Force of Columns

\begin{tabular}{|c|c|c|c|c|c|c|c|c|c|c|}
\hline \multirow{2}{*}{ Column } & & \multicolumn{3}{|c|}{ Without Tsunami Load } & \multicolumn{3}{c|}{ With Tsunami Load } & \multicolumn{3}{c|}{ Different (\%) } \\
\cline { 2 - 11 } & & $\mathbf{P}(\mathbf{k N})$ & $\mathbf{V}(\mathbf{k N})$ & $\mathbf{M}(\mathbf{k N m})$ & $\mathbf{P}(\mathbf{k N})$ & $\mathbf{V}(\mathbf{k N})$ & $\mathbf{M}(\mathbf{k N m})$ & $\mathbf{P}$ & $\mathbf{V}$ & $\mathbf{M}$ \\
\hline K1 (Ø60) & $\mathrm{C}$ & -2257 & -133 & -208 & -2570 & -191 & -323 & 12.1 & 30.3 & 35.6 \\
\cline { 2 - 11 } Exterior & $\mathrm{T}$ & 709 & 128 & 212 & 709 & 212 & 288 & 0.0 & 39.6 & 26.3 \\
\hline K1 (Ø60) & $\mathrm{C}$ & -1725 & -93 & -170 & -1719 & -133 & -208 & 0.3 & 30.0 & 18.2 \\
\cline { 2 - 11 } Interior & $\mathrm{T}$ & 235 & 104 & 181 & 462 & 123 & 212 & 49.1 & 15.4 & 14.6 \\
\hline K1 (60.40) & $\mathrm{C}$ & -1042 & -46 & -166 & -920 & -663 & -330 & 13.2 & 93.0 & 49.6 \\
\cline { 2 - 11 } Exterior & $\mathrm{T}$ & 174 & 176 & 173 & 263 & 176 & 173 & 33.8 & 0.0 & 0.0 \\
\hline K1 (60.40) & $\mathrm{C}$ & -1364 & -268 & -159 & -378 & -163 & -77 & 260.8 & 64.4 & 106.4 \\
\cline { 2 - 10 } Exterior & $\mathrm{T}$ & 0.6 & 260 & 146 & 379 & 163 & 94 & 99.8 & 59.5 & 55.3 \\
\hline
\end{tabular}

Table 5: Internal Force of Beams

\begin{tabular}{|c|c|c|c|c|c|c|c|}
\hline \multirow{2}{*}{ Column } & & \multicolumn{2}{|c|}{ Without Tsunami Load } & \multicolumn{2}{c|}{ With Tsumami Load } & \multicolumn{2}{c|}{ Different (\%) } \\
\cline { 2 - 8 } & $\mathbf{V}(\mathbf{k N})$ & $\mathbf{M}(\mathbf{k N m})$ & $\mathbf{V}(\mathbf{k N})$ & $\mathbf{M}(\mathbf{k N m})$ & $\mathbf{V}$ & $\mathbf{M}$ \\
\hline BA1 (40x60) & $\mathrm{C}$ & -257 & -277 & -191 & -323 & 34.4 & 16.8 \\
\cline { 2 - 8 } 2nd Floor & $\mathrm{T}$ & 261 & 176 & 212 & 288 & 18.5 & 63.0 \\
\hline BB1 (40x50) & $\mathrm{C}$ & -228 & -271 & -319 & -349 & 40.2 & 28.9 \\
\cline { 2 - 8 } 2nd Floor & $\mathrm{T}$ & 184 & 256 & 184 & 329 & 0.05 & 28.2 \\
\hline BC1 (30x30) & $\mathrm{C}$ & -68 & -70 & -17 & -20 & 74.2 & 71.5 \\
\cline { 2 - 8 } 2nd Floor & $\mathrm{T}$ & 51.9 & 61.5 & 17.38 & 18.15 & 66.5 & 70.5 \\
\hline
\end{tabular}

\subsection{Load-bearing capacity of Structure}

Load-bearing capacity of the structure building, such as columns and beams, were calculated through P-M interaction diagram and shear capacity for columns, and the flexural and shear capacities for beams.

\subsubsection{Load-bearing Capacity of Columns}

P-M Interaction diagram is a diagram that illustrates the ability or capacity of the column is based on the relationship between the bending moment and axial loads in column. Figures 13 and 14 show the interaction P-M diagram obtained from structural analysis results of the shelter building with and without tsunami loads, respectively.

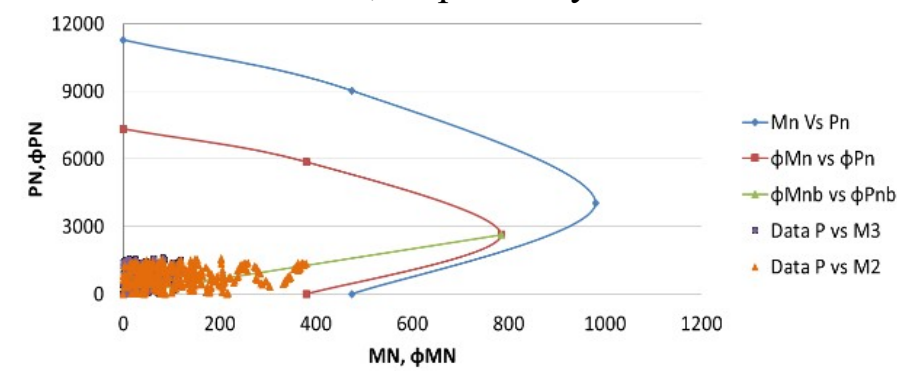

(a) $\mathrm{K} 1(\varnothing 60 \mathrm{~cm})$ at $1 \mathrm{st}$ floor (Interior)

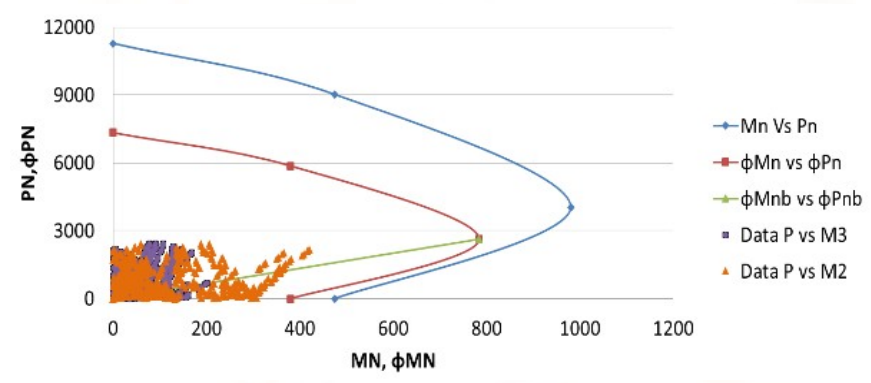

(b) $\mathrm{K} 1(\varnothing 60 \mathrm{~cm})$ at $1 \mathrm{st}$ floor (Exterior)

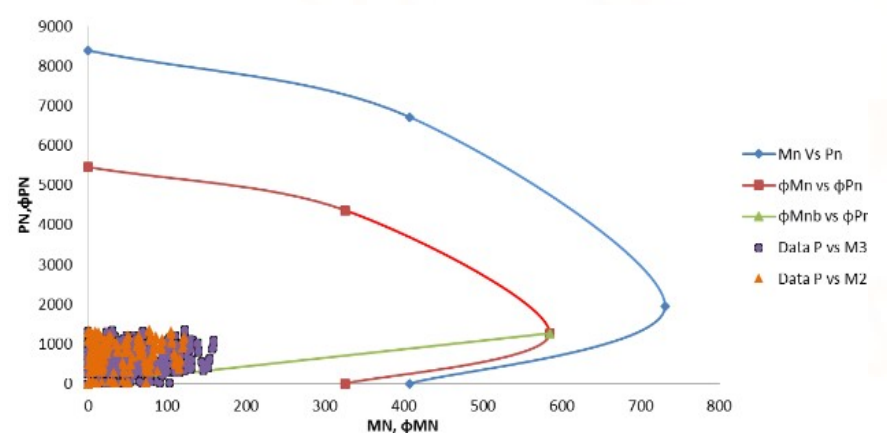

(c) K2 $(60 \times 40 \mathrm{~cm})$ at $1 \mathrm{st}$ floor (Interior) 


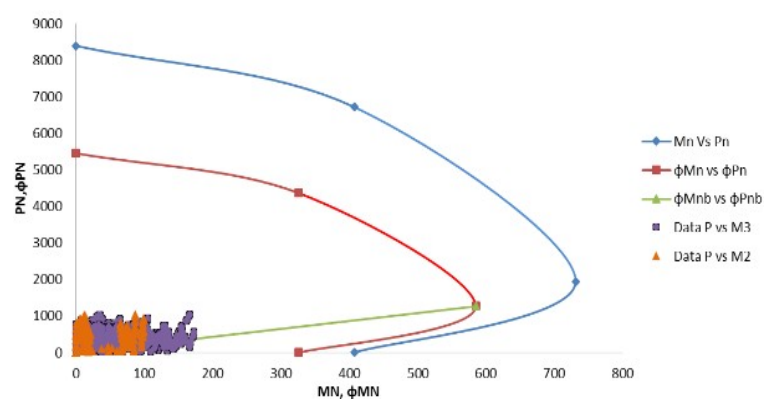

(d) K2 $(60 \times 40 \mathrm{~cm})$ at 1st floor (Exterior)

Figure13. Interaction P-M diagram of column without tsunami loads

Based on the P-M diagram of column in the structures impacted tsunami loads (Fig. 15), it appears that the axials and moments of the columns on the 1 st floor were outside the interaction diagram. This indicates that the columns are not strong enough to resist the working loads including tsunami loads. The column should be retrofitted if the shelter still use as a vertical evacuation building for tsunami.

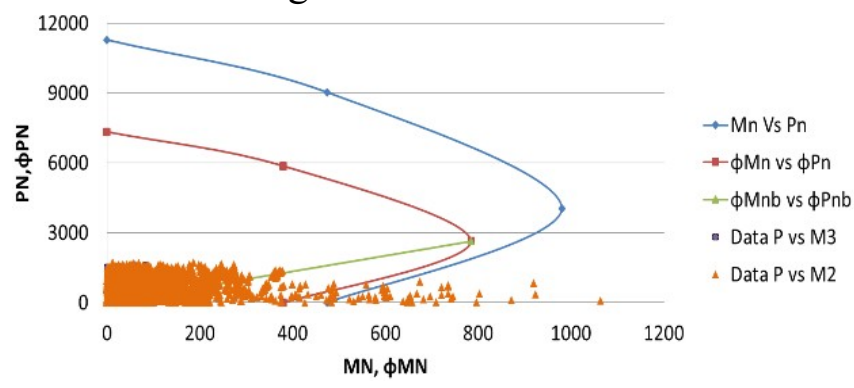

(a) K1 $(\varnothing 60 \mathrm{~cm})$ at $1 \mathrm{st}$ floor (Interior)

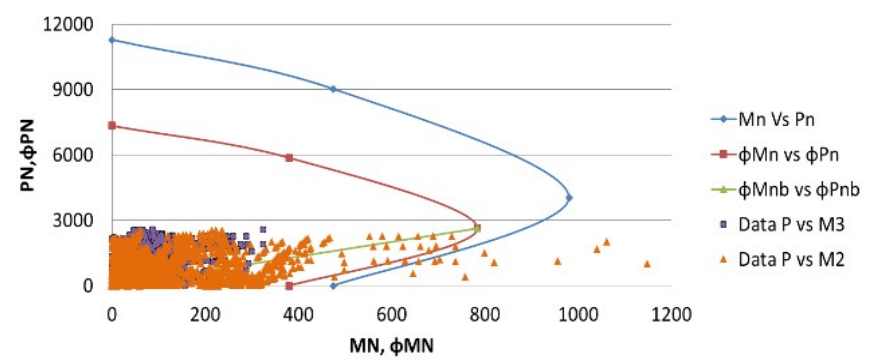

(b) K1 $(\varnothing 60 \mathrm{~cm})$ at $1 \mathrm{st}$ floor (Exterior)

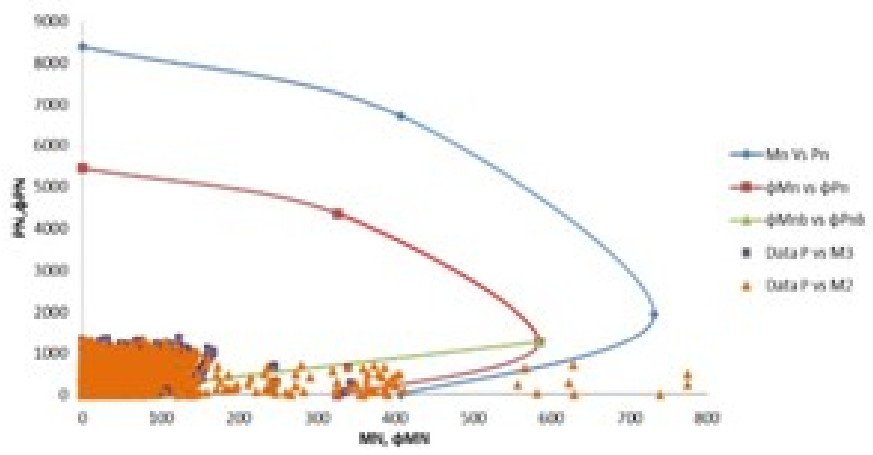

(c) $\mathrm{K} 2(60 \times 40 \mathrm{~cm})$ at $1 \mathrm{st}$ floor (Interior)

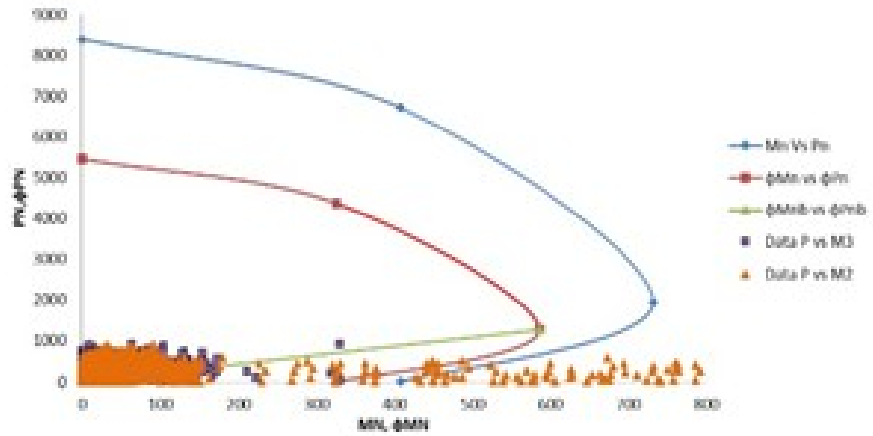

(d) K2 $(60 \times 40 \mathrm{~cm})$ at 1 st floor (Exterior)

Figure14. Interaction P-M diagram of column with tsunami loads

\subsubsection{Load-bearing Capacity of Beams}

Tables 6 to 9 show the flexural and shear capacity of the beam with and without tsunami loads. From Table 7 , it can be seen that the flexural capacity of beams in 2nd floor are not strong enough to resist the working loads. This means the beam should be strengthened. Meanwhile, the shear capacity of the beams is strong enough and able to withstand the working loads (Table 9).

Table 6: Flexure Capacity of Beam without Tsunami Loads

\begin{tabular}{|c|c|c|c|c|c|c|}
\hline \multirow{2}{*}{ Beam } & \multicolumn{2}{|c|}{ Num. of Bar } & \multirow{2}{*}{$\begin{array}{l}\text { (DMnn } \\
(\mathrm{kN})\end{array}$} & \multirow{2}{*}{$\begin{array}{l}\text { Mu } \\
(\mathrm{kN})\end{array}$} & \multicolumn{2}{|c|}{ Note } \\
\hline & Tens. & Com. & & & $\mathrm{MIu}$ & $\leq \mathrm{Mn}$ \\
\hline BA1 & 6D22 & $3 \mathrm{D} 22$ & 395 & 277 & $\mathrm{P}$ & $\mathrm{OK}$ \\
\hline $40 / 60$ & 4D22 & $2 \mathrm{D} 22$ & 265 & 176 & $\mathrm{M}$ & $\mathrm{OK}$ \\
\hline BB1 & 6D22 & $3 \mathrm{D} 22$ & 322 & 271 & $\mathrm{P}$ & OK \\
\hline $40 / 50$ & 4D22 & 2D22 & 271. & 256 & $\mathrm{M}$ & NOT \\
\hline $\mathrm{BC} 1$ & 4D22 & $4 \mathrm{D} 22$ & 119 & 70 & $\mathrm{P}$ & $\mathrm{OK}$ \\
\hline $30 / 30$ & 4D22 & 4D22 & 119 & 61 & $\mathrm{M}$ & $\mathrm{OK}$ \\
\hline
\end{tabular}

Table 7: Flexure Capacity of Beam with Tsunami Loads

\begin{tabular}{|c|c|c|c|c|c|c|}
\hline \multirow{2}{*}{ Beam } & \multicolumn{2}{|c|}{ Num. of Bar } & \multirow{2}{*}{$\begin{array}{l}\text { (D)Mn } \\
(\mathrm{kN})\end{array}$} & \multirow{2}{*}{$\begin{array}{l}\text { Mu } \\
(\mathbf{k N})\end{array}$} & \multicolumn{2}{|c|}{ Note } \\
\hline & Tens. & Com. & & & $\mathrm{M} \mathrm{u}$ & $\leq \mathrm{M} \ln$ \\
\hline BA1 & $6 \mathrm{D} 22$ & 3D22 & 395 & 323 & $\mathrm{P}$ & $\mathrm{OK}$ \\
\hline $40 / 60$ & 4D22 & 2D22 & 265 & 288 & $\mathrm{M}$ & NOT \\
\hline BB1 & $6 \mathrm{D} 22$ & $3 \mathrm{D} 22$ & 322 & 349 & $\mathrm{P}$ & NOT \\
\hline $40 / 50$ & 4D22 & 2D22 & 271. & 329 & $\mathrm{M}$ & NOT \\
\hline $\mathrm{BC} 1$ & 4D22 & 4D22 & 119 & 20 & $\mathrm{P}$ & $\mathrm{OK}$ \\
\hline $30 / 30$ & 4D22 & 4D22 & 119 & 18 & $\mathrm{M}$ & $\mathrm{OK}$ \\
\hline
\end{tabular}


Table 8: Shear Capacity of Beam with Tsunami Loads

\begin{tabular}{|c|c|c|c|c|}
\hline \multirow{2}{*}{ Beam } & $\mathbf{d V n}$ & $\mathbf{V u}$ & \multicolumn{2}{|c|}{ Note } \\
\cline { 4 - 5 } & $(\mathrm{kN})$ & $(\mathrm{kN})$ & $\mathbf{M} \mathbf{u}$ & $\leq \mathbf{M n}$ \\
\hline BA1 & 514 & 257 & $\mathrm{P}$ & $\mathrm{OK}$ \\
\cline { 2 - 5 } $40 / 60$ & 335 & 261 & $\mathrm{M}$ & $\mathrm{OK}$ \\
\hline $\mathrm{BB} 1$ & 424 & 228 & $\mathrm{P}$ & $\mathrm{OK}$ \\
\cline { 2 - 5 } $40 / 50$ & 276 & 184 & $\mathrm{M}$ & $\mathrm{OK}$ \\
\hline $\mathrm{BC} 1$ & 315 & 68 & $\mathrm{P}$ & $\mathrm{OK}$ \\
\cline { 2 - 5 } $30 / 30$ & 315 & 51 & $\mathrm{M}$ & $\mathrm{OK}$. \\
\hline
\end{tabular}

Table 9: Shear Capacity of Beam with Tsunami

\begin{tabular}{|c|c|c|c|c|}
\hline \multirow{2}{*}{ Beam } & $\mathbf{d V n}$ & $\mathbf{V u}$ & \multicolumn{2}{|c|}{ Note } \\
\cline { 4 - 5 } & $(\mathbf{k N})$ & $(\mathbf{k N})$ & $\mathbf{M} \mathbf{u}$ & $\leq \mathbf{M n}$ \\
\hline BA1 & 514 & 191 & $\mathrm{P}$ & $\mathrm{OK}$ \\
\cline { 2 - 5 } $40 / 60$ & 335 & 212 & $\mathrm{M}$ & $\mathrm{OK}$ \\
\hline $\mathrm{BB} 1$ & 424 & 319 & $\mathrm{P}$ & $\mathrm{OK}$ \\
\cline { 4 - 5 } $40 / 50$ & 276 & 184 & $\mathrm{M}$ & $\mathrm{OK}$ \\
\hline BC1 & 315 & 17 & $\mathrm{P}$ & $\mathrm{OK}$ \\
\cline { 2 - 5 } $30 / 30$ & 315 & 17 & $\mathrm{M}$ & $\mathrm{OK}$. \\
\hline
\end{tabular}

\section{Conclusion}

The addition tsunami loads on the shelter building affect load-bearing capacity of shelter structure. The capacity of columns on 1st floor and beams on the 2nd floor are not strong enough to resist the working loads.

Tsunami loads on the structure building increase the column internal forces by around 5-27\%, 9-49\%, and $18-49 \%$, for axial, shear and bending moment respectively. Similarly, the beam internal forces increase by around $7-39 \%$ and $8-45 \%$, for shear and bending moment respectively. The higher of the forces especially occurs in the columns of the 1 st floor and in the beams on the 2 nd floor.
The Ulak Karang shelter should be retrofitted before it is used as a vertical evacuation building for tsunami.

\section{References}

1. FEMA P-646, 2012, Guidelines for Design of Structures for Vertical Evacuation from Tsunamis Applied Technology Council, Redwood City California

2. Natawidjaja, D., H., K., and J., Suprijanto, 1995 Gempa Bumi Tektonik, In Annual Convention of Geoteknologi : LIPI.

3. Natawidjaja, D., H., 2002, Ph., D Thesis, Institute of Technology : California.

4. Nazwil, 2007, Wilayah Rawan Tsunami, Skripsi Departemen Geografi FMIPA UI, Jakarta.

5. SNI 2847-2013, "Persyaratan Beton Struktural Untuk Bangunan Gedung”.

6. SNI 03-1726-2002, "Tata Cara Perencanaan Ketahanan Gempa Untuk Bangunan Gedung”, Indonesia.

7. SNI 1726-2012, “Tata Cara Perencanaan Ketahanan Gempa Untuk Bangunan Gedung dan Non Gedung", Indonesia.

8. Yudhicara, 2008, Kaitan Antara Karakteristik Pantai Provinsi Sumatera Barat Dengan Potensi Kerawanan Tsunami, Pusat Vulkanologi Dan Mitigasi Bencana Geologi: Bandung.

9. Lambourne, H., (March 2005), "Tsunami: Anatomy of a Disaster", BBC News, Link: http://news.bbc.co.uk/2/hi/science/nature/4381395 . stm. 